STEPHEN IORNS

\title{
Unfair Terms in Standard Form Consumer Contracts
}

\author{
LLM RESEARCH PAPER \\ LAWS 532: CONSUMER LAW
}

\section{FACULTY OF LAW}

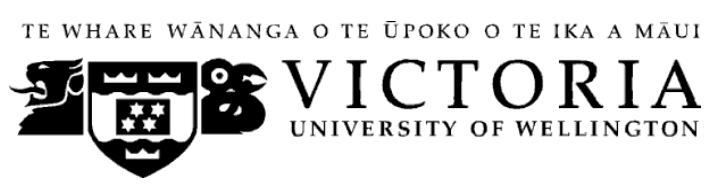

2014 


\section{Contents (References - table of contents)}

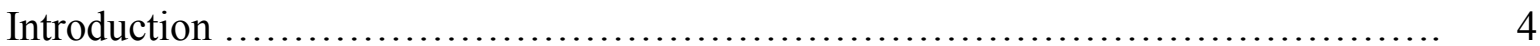

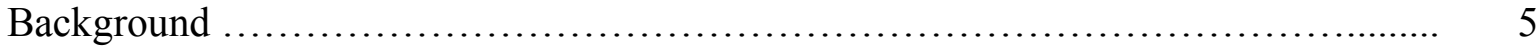

The Justification for Protection against unfair terms ........................... 6

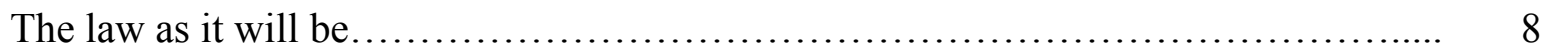

Consumer Contracts..................................................... 8

Standard Term Contracts.............................................. 9

Unfair Terms......................................................... 10

Significant Imbalance................................... 10

Reasonable Necessity...................................... 12

Detriment................................................ 13

Examples............................................... 13

Exemptions............................................ 14

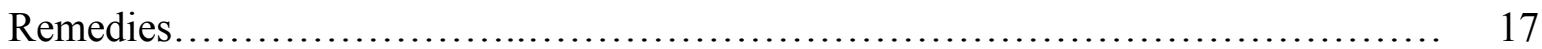

The Omission of Debate on Enforcement Provisions..................... 18

The implication of excluding private remedies......................... 19

Effect of a Declaration .................................................. 20

Conclusion.............................................................. 22 


\section{Abstract}

This paper explores the amendments to the Fair trading Act 1986 introducing provisions preventing the use of unfair terms in standard form consumer contracts. The amendments are drafted in close line with Australian federal and state legislation addressing unfair terms. This paper outlines the provisions, identifies two key differences between the Australian and New Zealand legislation, and argues that as a result of those differences the protection will not be effective. The ultimate conclusion reached is that consumers in New Zealand are now protected from unfair terms within standard form contracts in form but not substance.

\section{Word length}

The text of this paper (excluding abstract, table of contents, footnotes and bibliography) comprises approximately 6,846 words.

\section{Subjects and Topics}

Fair trading Act 1986

Consumer Law

Unfair Terms

Standard Form Contracts 


\section{Introduction}

On 17 March 2015, amendments to the Fair Trading Act 1986 ("FTA") preventing unfair terms within standard form consumer contracts will come in to force in New Zealand. ${ }^{1}$ This paper explores the law as it will be, and discusses the jurisdictional hurdles one must pass to benefit from unfair terms protection. In undertaking a comparison with Australia, it is clear that the new provisions fall short when compared with the Australian Consumer Law ("ACL"). ${ }^{2}$ While these changes have been heralded as empowering consumers and aligning our laws with the $\mathrm{ACL}^{3}$ there are a number of very big differences. Firstly, there is one glaring omission: the right for consumers to take direct action in the Courts where terms are potentially unfair. A term in a standard form consumer contract is only deemed to be unfair once it has been declared unfair by the Court, on application by the Commerce Commission. ${ }^{4}$ The Commerce Commission is the only party that may apply for such a declaration. ${ }^{5}$ This is quite a different position to that in Australia, where a variety of private remedies are available for consumers, and a number of public entities can apply for a declaration.

Secondly, there has been a significant departure in the definition of upfront price, which is relevant by virtue of the status upfront price terms have, of being exempt from considerations of unfairness. While the ACL specifically excludes contingency payments (payments that may be due in the future if something happens or does not happen) from falling within the definition of upfront price, the new provisions of the FTA specifically include them in the definition of upfront price.

This paper argues that the end result of the absence of private remedy coupled with extension of the exclusion to include contingency payments, leaves a consumer law that has been strengthened in form but not in substance. The legislative process is silent on the reasons behind omitting private remedies and departing significantly from the ACL. This paper will explore the competing interests that have been balanced by the legislature in enacting these provisions.

\footnotetext{
${ }^{1}$ All references in this paper to the Fair Trading Act 1986 are to the Act as amended in 2013, despite provisions not yet being in force.

${ }^{2}$ The Australian Consumer Law can be found in Schedule 2 of the Competition and Consumer Act 2010 (Australian Commonwealth Legislation).

3 Parliamentary press release, Hon Craig Foss, Minster of Consumer Affairs, 10 December 2013 $<$ http://www.beehive.govt.nz/release/consumer-law-reform-bill-passes-third-reading>

${ }^{4}$ Sections 2(1), 26A, 46H, Fair Trading Act 1986.

${ }^{5}$ Section $46 \mathrm{H}$.
} 
Whatever the reasoning behind the unfair terms provisions as enacted, it is unclear which approach the courts will take once a term has been declared unfair: will the declaration apply to all identical terms, or will the declaration be limited to one particular standardform contract? What is the effect of a declaration to the consumer? The general remedies in Part 5 of the FTA are available once a declaration has been made, but, will they assist? This paper explores the practical implications of this for both businesses and consumers.

\section{Background}

In conducting the biggest overhaul of our consumer laws in over 20 years, unfair terms were nearly overlooked. In the first reading of the Consumer Law Reform Bill, ("the Bill") the Minster of Consumer Affairs noted that one objective was to harmonize our consumer laws with the Australian Consumer Law. He noted that unfair terms had been considered, but were not included in the bill. The Minister asked the Select Committee to specifically consider whether the Fair Trading Act ought provide for protections against unfair terms.

The Commerce Committee duly undertook their task, reporting back on the matter as follows: ${ }^{6}$

We recommend the addition of [...] a new section 26A in Part 1 of the Fair Trading Act. New section 26A would prohibit the use of unfair contract terms in standard form contracts. Contravention of this prohibition would give rise to the remedies described in Part 5 of the Fair Trading Act.

A term is an unfair contract term only if it is declared to be such by the High Court or a District Court, on the application of the Commerce Commission. This process would ensure that the Commerce Commission was given control of the enforcement of unfair contract terms. To provide for this process, we recommend inserting new clause $26 \mathrm{~A}$, which would insert new sections $46 \mathrm{H}$ to $46 \mathrm{M}$. These provisions set out the power of a court to declare a term in a standard form consumer contract to be unfair, and the basis for such a declaration. These provisions reflect the essential features of the Australian Consumer Law provisions relating to unfair contract terms. A "grey list" of examples of unfair contract terms is included in new section 46M, replicating the list in the Australian Consumer Law.

${ }^{6}$ Consumer Law Reform Bill 2012 (287-2), as reported from the Commerce Committee on 2 October 2012, p4. 
In moving for the second reading of the Bill, the Minister of Consumer Affairs endorsed the recommendation, stating: ${ }^{7}$

The Commerce Committee was asked to specifically examine whether to add to the bill unfair contract terms and unconscionable conduct provisions along the lines of such provisions in the Australian consumer law. Weighing up the views from both businesses and consumer representatives, the committee has recommended adding provisions dealing with unfair terms in standard form contracts into the Fair Trading Act. [...] Only the Commerce Commission will be allowed to take action to have a term in a contract declared unfair. The bill also includes a list of examples, as are also listed in the Australian consumer law, which will give the courts additional guidance.

The Bill was then split with the relevant provisions being included in the Fair Trading Amendment Act 2013, which passed with cross-party support.

\section{The Justification for protection against Unfair Terms}

Classic considerations of contract law have historically recognised the freedom to contract as justification to decline looking to the inherent fairness of terms parties have agreed to. ${ }^{8}$ It has generally been seen as the consumers' duty to negotiate terms with suppliers. As our marketplace has developed, though, the use of standard form contracts has grown exponentially. These are now routinely used for both luxury items and essential services. Whether utilised by power companies, telecommunication companies, gyms, technology companies or consumer financers, terms dictated by supplier to consumer are now routinely agreed to by consumers with little or no appreciation of their implications. In an alarmingly large number of transactions, the contracts have not even been read by the consumer. As Omri Ben-Shahar asserts: ${ }^{9}$

Real people don't read standard form contracts. Reading is boring, incomprehensible, alienating, time consuming, but most of all pointless. We want the product, not the contract. Besides, lots of people bought the product or the service along with the same contract and seem happy enough, so we presume that there must be nothing particularly important buried in the contract terms.

\footnotetext{
${ }^{7}$ NZPD, 11 December 2012. Volume 686 Page 7410.

${ }^{8} \mathrm{~S}$ G Corones (ed) The Australian Consumer Law ( $2^{\text {nd }}$ Ed, Thompson Routers, Sydney, 2012) at $[6.05]$.

9 O Ben-Sharhar, The Myth of the "Opportunity to Read" in Contract Law [2009] 1 ERCL 1; Electronic copy available at: http://ssrn.com/abstract $=1162922$
} 
Analysis from a behavioral science perspective suggests that not only is the lack of comprehension an issue, but there are a variety of factors present which ensure a great deal of standard form contracts will be accepted without much thought. ${ }^{10}$ Whether this is due to the fact they are presented at the end of a transaction, when a product or service has already been chosen, or whether this is due to the reality that where a consumer receives the contract, they will look for favourable terms to confirm their decision to purchase, the end result is the same: standard form consumer contracts will not be effectively read and understood, in a very high percentage of transactions. This leaves a situation where the classical contract law theories that assume effective negotiation, and a freedom to choose to enter a contract with any terms, are simply stretched too far. When we know that consumers will not read standard form contracts, and even if they did, that they would not effectively evaluate them, there lies a strong justification for preventing traders from exploiting this knowledge and relying upon onerous, objectively unfair terms.

Not only does the behavioral science analysis provide justification for legislative change, but real world examples showed that the classic contract law failed to assist with situations arising under standard form consumer contracts. The Commerce Commission in making its submission to the Select Committee (supporting introduction of unfair terms provisions) gave three examples of recent cases bought to its attention, which could have been better handled with protection for consumers for unfair terms. In the first example, a telecommunications company had unilaterally raised a consumer's monthly plan price, in reliance on their standard form contract. This occurred six months in to a two year plan, and the company insisted that a significant termination fee would be charged if the customer cancelled their plan in protest to this unilateral price rise. ${ }^{11}$

In the second example, a residential home "rent to own" scheme granted consumers a right to occupy a property for 30 years, under an installment agreement. The occupiers had to pay for repairs on the company's insistence, and, if they missed any payment over that 30 year term, the agreement could be terminated at the option of the company, with the consumer losing their entire interest in the property. ${ }^{12}$

${ }^{10}$ S I Becher Behavioural Science and Consumer Standard Form Contracts [2007] Louisiana Law Revue Vol. 68, at page 117.

${ }^{11}$ Submission by the Commerce Commission to the Commerce Committee on the Consumer Law Reform Bill, dated March 2012, p 13 at 54.1.

12 Ibid, p13 at 54.2. 
In the third example, a company leased out water filters for a two year period at a weekly price. Without clear disclosure, the standard form contract automatically rolled over for a further two year period if a right to purchase or cancel was not elected within seven days of the expiration of the two year term. ${ }^{13}$

Under the classic considerations of contract law, on the face of it the inherent objective unfairness of these provisions would be virtually irrelevant, in the absence of some form of misrepresentation or other questionable conduct leading to the formation of the contract. For that reason, that the Commerce Commission recommended the inclusion of a prohibition against Unfair Contract Terms in the Fair Trading Act 1986 ("FTA"), identical to those contained in the Australian Consumer Law.

\section{The law as it will be}

The additions to the FTA ought do what they say they will; prohibit unfair terms in standard form consumer contracts. Whether or not they will achieve their objective is discussed below, after the legislative framework has been explained. In applying these provisions, the first task will be to assess whether a particular contract is a consumer contract, and if so, whether it is a standard form one.

\section{A Consumer Contract}

In the FTA: ${ }^{14}$

Consumer contract means a contract,-

(a) in the case of a contract relating to goods or services, between-

(i) at least 1 supplier supplying the goods or services in trade; and

(ii) at least 1 consumer; and

(b) in the case of a contract relating to the sale or grant of an interest in land, between-

(i) at least 1 person disposing, in trade, of an interest in the land; and

(ii) at least 1 person acquiring an interest in the land for personal, domestic, or residential purposes

Consumer means a person who-

(a) acquires from a supplier goods or services of a kind ordinarily acquired for personal, domestic, or household use or consumption; and

\footnotetext{
${ }^{13}$ Ibid, p 13, 54.3.

${ }^{14}$ Section 2(1).
} 
(b) does not acquire the goods or services, or hold himself or herself out as acquiring the goods or services, for the purpose of-

(i) resupplying them in trade; or

(ii) consuming them in the course of a process of production or manufacture; or

(iii) in the case of goods, repairing or treating, in trade, other goods or fixtures on land

In plain terms, the goods or services must be of an essentially domestic or personal kind, as opposed to commercial. ${ }^{15}$

This position is notably different to that in Australia, which includes a nearly identical definition, but also extends the status of consumer to parties acquiring goods or services valued at under $\$ 40,000.00 .{ }^{16}$ While the FTA could have been amended to bring the New Zealand definition of consumer in line with that in Australia, the legislature has opted to retain the definition as found in the Consumer Guarantees Act 1993.

\section{B Standard Form Contracts}

The Court may only determine that a contract is a standard form contract if there has not been effective negotiation between the parties as to the terms (other than the key terms, such as the main subject matter and price). ${ }^{17}$

In making its determination, the Court is given mandatory considerations: ${ }^{18}$

(a) whether one of the parties has all or most of the bargaining power relating to the transaction:

(b) whether the contract was prepared by one or more parties before any discussion relating to the transaction occurred with the other party or parties:

(c) whether 1 or more of the parties was, in effect, required either to accept or reject the terms of the contract (other than terms referred to in section $46 \mathrm{~K})$ in the form in which they were presented:

\footnotetext{
${ }^{15}$ New Zealand Commerce Commission Draft Unfair Contract Terms Guidelines (July 2014), p2 at 7.2.

${ }^{16}$ Section 3(1), ACL.

${ }^{17}$ Section 46J.

${ }^{18}$ Section $46 \mathrm{~J}(2)$.
} 
(d) the extent to which the parties had an effective opportunity to negotiate the terms (other than terms referred to in section $46 \mathrm{~K}$ ) of the contract:

(e) the extent to which the terms of the contract take into account the specific characteristics of any party to the contract.

The terms referred to in Section $46 \mathrm{~K}$ are exempt from consideration at this stage, and when it comes to the unfairness consideration. These are examined in more detail below, but, for present purposes the exempt provisions are those which relate to the main subject matter of the contract, the upfront price, or, one that is expressly permitted or required by any enactment. ${ }^{19}$

\section{Unfair Terms}

It is only once we have passed the jurisdictional threshold, establishing that we are dealing with a standard form consumer contract, that we can consider whether there are terms that are unfair. In order for the Court to declare a term to be unfair, the term must 1) cause a significant imbalance in the party's rights and obligations under the contract, 2) not be reasonably necessary to protect a legitimate interest of the advantaged party, and 3 ) cause detriment to a party if relied upon or enforced. ${ }^{20}$ All of those conditions must be met. In determining whether or not a term is unfair, the Court must consider the transparency of the clause and the contract as a whole. ${ }^{21}$

The new provisions do not elaborate in great detail on these concepts. However, sections 46L(1) and (2), which set out the test to be applied are identical to Sections 24 (1) and (2) of the Australian Consumer Law. We can expect the Courts to take the Australian (and UK) position in to consideration when developing a body of case law.

\section{Significant Imbalance}

\footnotetext{
19 Section $46 \mathrm{~K}$.

${ }^{20}$ Section 46L(1).

${ }^{21}$ Section 46L(2).
} 
The Commerce Commission have identified in their draft guidelines regarding unfair terms that there is a causal connection required in this test, and a magnitude assessment. Essentially, the term must create the imbalance and that imbalance must be significant. ${ }^{22}$

The Australian commentary suggests that: ${ }^{23}$

[..] it appears that "significant" in s 24(1)(a) of the ACL means an imbalance of bargaining power that is "meaningful" or "of consequence" and "more than trivial", such that it is deserving of the intervention of the court to avoid the realized or likely consumer detriment.

The requirement for a significant imbalance was present in the Victorian legislation. Director of Consumer Affairs Victoria v AAPT Limited [2006] VCAT 1493, decided under that legislation, provides some examples of terms that were considered to create a significant imbalance: ${ }^{24}$

Variations: We may vary any term of this Agreement at any time in writing. To the extent required by any applicable laws or determinations made by the Australian Communications Authority (ACA), we will notify you of any such variation.

Suspension: We reserve the right to suspend provision of Services to you, where charges owing to us or any amount owing under this clause remains outstanding after 60 days, unless we have received written notice from you disputing those charges in good faith. If we suspend or terminate the Services for unpaid charges or any other reason, subsequent reconnection may incur a reconnection fee.

Immediate Termination: We may terminate this agreement immediately by notice to you if:

(a) You have breached this Agreement;

(b) ...; or

(c) You change your address of billing contact details without notifying us in accordance with clause 7.4.

10.4 You remain liable for all charges payable under the Agreement in respect of Services up to the time of Termination.

\footnotetext{
${ }^{22}$ New Zealand Commerce Commission Draft Unfair Contract Terms Guidelines (July 2014) p8 at [39].

${ }^{23}$ Ibid at 8, p236 at [6.95].

${ }^{24}$ Director of Consumer Affairs Victoria v AAPT Limited [2006] VCAT 1493, referred to in S G Corones The Australian Consumer Law ibid at 8, at [6.100].
} 
The examples given in Director of Consumer Affairs Victoria v AAPT confirm the view that where a term provides a significant imbalance, whether through broad application or unilateral rights to one party, but not the other, they will be reasonably easy to assess: the Courts will know it when they see it, and consumers ought be able to grasp the concept.

Considering the words of the enactment and in light of its purpose, we can confidently expect the New Zealand Courts will consider this limb of the test on a case by case basis, weighing up the imbalance caused by a particular term in line with the Victorian approach.

\section{Reasonable necessity}

The second consideration in determining whether a term is unfair requires establishing that the term is not reasonably necessary to protect the legitimate interests of the party relying on it. That being said, the evidential onus lies with the party whose interest it is designed to protect. $^{25}$

This essentially requires considering first whether there is a legitimate interest to protect, then, whether the term is reasonable in and of itself. ${ }^{26}$

The Commerce Commission have stated their view that given the purpose of the Act, this provision places a high threshold on parties seeking to rebut the contrary presumption; their view is that a party would need to establish that the interest being protected by the term is 1) a legitimate interest that requires protection, and 2) it can not reasonably be protected by fairer means. ${ }^{27}$ That may be stating it a little too strong, though. A party tasked with discharging their evidential onus would need to satisfy the Court on balance that there was a legitimate interest that the term reasonably protects. Reference to fairer means may come in to the reasonableness consideration, but would not be conclusive on the question of reasonableness.

\footnotetext{
${ }^{25}$ Section 46L(3).

${ }^{26}$ Ibid at 8, p 237 at [6.105].

${ }^{27}$ Ibid at 19, p 9 at [45].
} 


\section{Detriment}

The final consideration for the determination of unfair terms requires the Court to be satisfied that the term would cause detriment (whether financial or otherwise) to a party if it were applied, enforced, or relied on. ${ }^{28}$

It is important to note that the Commission would not have to establish detriment, just, that detriment is possible under the term. As with considerations of detriment elsewhere in the law, it can be expected that the Courts will set the bar fairly low in this respect.

\section{Examples}

Section 46M of the FTA sets out a copy of the examples contained in the Australian Consumer Law:

Without limiting section 46I, the following are examples of the kind of terms that, if in a consumer contract, may be unfair contract terms:

(a) a term that permits, or has the effect of permitting, one party (but not another party) to avoid or limit performance of the contract:

(b) a term that permits, or has the effect of permitting, one party (but not another party) to terminate the contract:

(c) a term that penalises, or has the effect of penalising, one party (but not another party) for a breach or termination of the contract:

(d) a term that permits, or has the effect of permitting, one party (but not another party) to vary the terms of the contract:

(e) a term that permits, or has the effect of permitting, one party (but not another party) to renew or not renew the contract:

(f) a term that permits, or has the effect of permitting, one party to vary the upfront price (as defined in section $46 \mathrm{~K}(2)$ ) payable under the contract without the right of another party to terminate the contract:

(g) a term that permits, or has the effect of permitting, one party unilaterally to vary the characteristics of the goods or services to be supplied, or the interest in land to be sold or granted, under the contract:

(h) a term that permits, or has the effect of permitting, one party unilaterally to determine whether a contract has been breached or to interpret its meaning:

(i) a term that limits, or has the effect of limiting, one party's vicarious liability for its agents:

\footnotetext{
${ }^{28}$ Section $46 \mathrm{~L}(1)(\mathrm{c})$.
} 
(j) a term that permits, or has the effect of permitting, one party to assign the contract to the detriment of another party without that other party's consent:

(k) a term that limits, or has the effect of limiting, one party's right to sue another party:

(1) a term that limits, or has the effect of limiting, the evidence one party can adduce in proceedings relating to the contract:

(m) a term that imposes, or has the effect of imposing, the evidential burden on one party in proceedings relating to the contract.

This grey list of examples is identical to that contained in the ACL. Prior to the enactment of the ACL, Victoria was the only state that provided protection for consumers for unfair terms in standard form contracts. While the question of whether a term was unfair differed in that a "good faith" requirement was present, the grey list above is substantively identical to that previously enacted in Victoria.

In the leading case under the Victorian legislation, Jetstar Airways Pty Ltd v Free [2008] VSC 539, Cavanough J observed a common theme, describing the examples given: ${ }^{29}$

Each paragraph supplies an example of a term which may not only be described as one-sided but which also tends to derogate from the enforceability or value of a promise made by the supplier (or of a right conferred on the consumer) by another express or implied term of the contract. The making (knowingly) of an apparently binding but actually unenforceable or valueless promise is the kind of thing that any conventional understanding of contrariety to good faith might cover. A term which purported to authorise a supplier to resile from an important contractual promise, at least if the term were not specifically drawn to the consumer's attention beforehand, would surely be apt to create surprise on the part of the consumer.

While this aspect of the decision under Victorian legislation needs to be treated with caution, the underlying principles remain. These provisions are aimed to remedy onesided situations that are contrary to the interests of the party who is likely to enter the contract unaware of the terms.

\section{Exemptions}

Section $46 \mathrm{~K}$ of the Act sets out three categories of terms that are exempt from consideration under the unfair terms provisions. Specifically: ${ }^{30}$

${ }^{29}$ Jetstar Airways Pty Ltd v Free [2008] VSC 539, at [114]. 
46K Terms that may not be declared to be unfair contract terms

(1) A court may not declare a term in a standard form consumer contract to be an unfair contract term to the extent that the term-

(a) defines the main subject matter of the contract; or

(b) sets the upfront price payable under the contract; or

(c) is a term required or expressly permitted by any enactment.

(2) In this section, upfront price means the consideration (including any consideration that is contingent upon the occurrence or non-occurrence of a particular event) payable under the contract, but only to the extent that the consideration is set out in a term that is transparent.

At first glance, this appears to be identical to the provisions of the ACL. However, there is one crucial difference: ${ }^{31}$

26 Terms that define main subject matter of consumer contracts etc. are unaffected (1) Section 23 does not apply to a term of a consumer contract to the extent, but only to the extent, that the term:

(a) defines the main subject matter of the contract; or

(b) sets the upfront price payable under the contract; or

(c) is a term required, or expressly permitted, by a law of the Commonwealth, a State or a Territory.

(2) The upfront price payable under a consumer contract is the consideration that:

(a) is provided, or is to be provided, for the supply, sale or grant under the contract; and

(b) is disclosed at or before the time the contract is entered into;

but does not include any other consideration that is contingent on the occurrence or non-occurrence of a particular event. [emphasis mine.]

On the face of it, the types of terms exempt from considerations of fairness make sense. The main subject matter of the contract is going to be the goods or services that are being supplied. Those are invariably going to be at the forefront of the consumer's mind, and subject to much greater scrutiny than the other terms of the contract. Terms that are expressly permitted by law, are naturally excluded. For example, Section 40 of the Credit Contracts and Consumer Finance Act 2003 allows default interest rates to be prescribed; as such, default interest provisions can not be considered under the fairness provisions.

\footnotetext{
${ }^{30}$ Section $46 \mathrm{~K}$.

${ }^{31}$ Section 26, ACL.
} 
The upfront price, one would think, is equally as common sense. Price is the one thing that consumers will pay close attention to, and may have the opportunity to negotiate. As can be seen above, however, the FTA has departed significantly from the ACL, by taking the opposite approach in its definition. The FTA definition of upfront price includes contingency payments -that is, payments due on some future event. The full implications of this are anything but clear. In Australia, consumers are protected where an unfair term covers payments that are due resulting from the occurrence or non-occurrence of a particular event. The most obvious example one can foresee is a non-payment penalty, or an early termination fee. In New Zealand, these are potentially included in the upfront price and excluded from fairness consideration, by what some might view as a legislative fiction.

Not only does this appear to create a legal fiction, stretching the definition of upfront price to include contingency payments, but it appears to create a conflict with the grey list of examples provided to give the Courts guidance. As set out above, Section 46M(c) gives the example of a term that will always be unfair; one that penalizes one party, but not the other, for a breach or termination of the contract.

This appears to enable suppliers to include unfair payment terms that are clearly anticipated by Section $46 \mathrm{M}(\mathrm{c})$, so long as they are included in the upfront price. The Commerce Commission's view apparently differs; whether it is naïve or simply more sanguine, time will tell. In their Draft Unfair Contract Terms Guidelines they draw the distinction between an upfront price and a penalty, giving the following examples: ${ }^{32}$

An Airline offers cheap $\$ 50$ fares. Travellers who ask to change their flights after purchasing these fares are charged a fee of $\$ 250$.

The $\$ 250$ fee is likely to be an upfront price term. It is the consideration payable when the traveler asks to change their flight, and in exchange the airline provides a rescheduling service. As long as the price is transparent it will be exempt from challenge. However, if this charge constitutes a penalty (for example, because it manifestly exceeds the value of the service, and is in effect a sanction rather than a service fee) it could fall outside the exemption and be challenged as an unfair term.

One would think that a consumer would simply opt to purchase a second $\$ 50$ fare in this example, but in any event, it is not clear where a line would be drawn. The Commerce

${ }^{32}$ Ibid at $15, \mathrm{p} 15$. 
Commission suggest that penalties can be distinguished from price as a penalty does not involve an exchange. They give two examples of penalty clauses: ${ }^{33}$

A DVD rental contract specifies that a customer will be fined $\$ 20$ for each half-day that the DV is returned late. The initial hire cost is $\$ 3$ per day, and rentals are for 24 hours only. The $\$ 40$-per day fine is likely to be a penalty, as it manifestly exceeds the value of the service being provided and does not reflect the business' costs or losses on the late return of the DVD.

Sarah joins a gym for a one-year minimum term. Her membership contract states that the gym may terminate the contract at any time without penalty, but that if Sarah decides to terminate the contract she must pay for the rest of the minimum term. When Sarah terminates the contract, she is denied all the benefits of membership but must pay for the remainder of the term. This is a penalty for termination clause.

These examples do not assist, as quite frankly, they are so clearly penalties that they could not be said to be part of the upfront price. The commission acknowledges that " $[\mathrm{t}]$ he distinction between a price and penalty is not always easy to draw, and each situation will be assessed on its particular facts." 34

New Zealand consumers are going to have a significantly harder time distinguishing what is part of the upfront price than their Australian counter-parts. While we may be able to look to other jurisdictions to assist with the distinction between a price and a penalty, Australia will be of little assistance, as we have departed from the ACL. The United Kingdom may assist, but, there is significant room to argue that as long as a term is transparent in setting out the costs on each event, whether it is a penalty in nature is irrelevant. All a transparent clause needs to do is provide for any consideration that is contingent upon the occurrence or non-occurrence of a particular event, and it will be an exempt term for the purposes of a declaration for unfairness.

\section{$V$ Remedies}

In New Zealand, the only party able to seek a declaration and thus remedy an unfair term is the Commerce Commission. ${ }^{35}$ Any person can ask the Commission to apply to the court for a declaration, ${ }^{36}$ but, the Commission is not bound to do so.

\footnotetext{
33 Ibid at $15, \mathrm{p} 16$.

${ }^{34}$ Ibid at 15 , p16, para 87.

35 Section $46 \mathrm{H}$.
} 
The ACL, on the other hand, allows a wide number of agencies to seek declarations, and enables a private litigant to seek a declaration that a term is unfair, ${ }^{37}$ an injunction preventing the use of the term, ${ }^{38}$ and seek a compensation order for any loss suffered. ${ }^{39} \mathrm{~A}$ defendant could also rely on the unfair terms provisions in any enforcement proceedings, as the terms do not require a declaration to be void; they simply need to pass the statutory test.

\section{A The omission of debate on enforcement provisions}

Hansard contains no mention, in either the second or third reading of the Bill, of this rather monumental departure from the ACL. Looking further back in the legislative process, however, sheds some light.

Prior to introduction of the Bill, in 2010 the Ministry of Consumer Affairs had released a discussion paper initially on consumer law reform more generally, then on the specific question of the introduction of unfair terms provision. ${ }^{40}$

The business community, unsurprisingly, came out in opposition of the introduction of unfair terms provisions. The ADSL Incorporated Society ("ADSL"), which primarily represents lawyers from Auckland, responded with opposition to the Ministry of Consumer Affairs additional paper on unfair terms. The ADLS was of the view that there was insufficient justification to include unfair terms provisions, and sufficient protection for consumers in the existing laws. For the event that unfair terms provisions would be introduced, the ADSL argued that their enforcement should be limited to public remedy, arguing that: ${ }^{41}$

\footnotetext{
${ }^{36}$ Section $46 \mathrm{H}(2)$.

${ }^{37}$ Australian Consumer Law, Section 250.

${ }^{38}$ Ibid, Section 232.

${ }^{39}$ Ibid, Section 237.

${ }^{40}$ Ministry of Consumer Affairs, Consumer Law Reform: A Discussion Paper, 2010; Consumer Law Reform Additional Paper, September 2010.

${ }^{41}$ Auckland District Law Society Inc, Commercial Law Committee Submissions to the Ministry of Consumer Affairs in Response to Consumer Law Reform Additonal Paper - September 2010 Unfair Contract Terms.
} 
Allowing civil enforcement will open a door for parties to exert pressure in relation to alleged unfair contract terms in order to procure settlement or outcomes favourable to them. In those circumstances, for many different reasons, businesses may be inclined to elect to settle even where the complaint is without merit. That may mean an alleged unfair term remains in use.

The Ministry's position is the perceived harm of unfair terms arises largely from standard form contracts. Given that view we consider that the regime should be seen as a benefit for society generally, rather than necessarily providing protection for individual parties to an agreement. Enforcement action will also benefit (or affect) a wider range of parties - including other individuals, and the relevant business or industry in general.

For those reasons, we are opposed to individual parties having rights to take civil action in relation to unfair contract terms, and seek damages or other relief. In our view, only the commerce commission (or other quasi-government agency) should be involved in the investigation and litigation of unfair terms, with the ability to seek declarations, penalties, and injunctions. Consideration would need to be given, however, to the downstream effect of the grant of declarations on the positions of parties to existing contracts in the market (and possibly the extent to which they should be able to bring action themselves).

But for the above, there is very little by way of reasoned argument on the exclusion of private remedies. In their report back to the house, the Select Committee was silent on the reasoning behind this exclusion. We can only assume that significant weight was given to the above passage.

\section{B The implication of excluding private remedies}

In the 2010 discussion paper issued by the Ministry of Consumer Affairs covering unfair terms specifically ("the 2010 discussion paper"), one of the questions asked was whether or not the Disputes Tribunal ought have jurisdiction to hear disputes arising from potentially unfair terms. This suggestion was largely opposed, due to the legal nature of any enquiry in to unfair terms, and the widely accepted fact that our Disputes Tribunal system is not adequately resourced to make delicate assessments of the law. Those are better left to the Courts. 
Implicit in the question of the Disputes Tribunal having jurisdiction is the notion that private remedies would be available. The counter-argument for recourse through the Disputes Tribunal lies at the heart of the issue here; objective unfairness is an issue and the ability for legislation to protect consumers from exploitation by suppliers is required. In order to achieve protection, any regime requires easy access for consumers.

In the absence of private remedies, we are faced with a range of potentially unjust situations, where suppliers will be able to rely on objectively unfair terms due to inaction by the Commerce Commission, coupled with an inability of the Courts to consider the relevant provisions in any other proceedings. Suppliers who have inserted objectively unfair terms in standard form consumer contracts will be able to enforce those terms until they have been declared unfair by the court on application from the Commerce Commission. Even once a particular term has been declared unfair, while the other customers of that particular supplier with identical contracts will obtain the benefit of a declaration, the same term may be relied upon by suppliers with different standard form contracts; what may be unfair on one contract will not automatically be unfair in another, when the contract as a whole must be looked at to assess unfairness.

While there is immense benefit in having a public body such as the Commerce Commission able to make such applications to the Court, it is without a doubt that they will not receive adequate resources to provide the same level of protection consumers in Australia enjoy.

\section{Effect of a Declaration}

Once a declaration has been obtained, its use is prohibited by Section 26A, which relevantly provides that:

(1) If a court has declared, under section 46I, that a term in a standard form consumer contract is an unfair contract term, a person must not-

(a) include the unfair contract term in a standard form contract (unless the term is included in a way that complies with the terms (if any) of the decision of the court); or

(b) apply, enforce, or rely on the unfair contract term in a standard form contract 
It is a criminal offence to breach Section 26A punishable by a fine of up to $\$ 600,000.00$ for a body corporate, or $\$ 200,000.00$ for an individual. ${ }^{42}$ There are a number of defences to prosecutions taken for breaching this provision, including reasonable mistake, and taking reasonable precautions to prevent the contravention of Section 26A. Offences under the FTA are, at least for misrepresentations, strict liability offences with no mens rea requirements. ${ }^{43}$ The same strict liability principle will almost certainly apply to this new offence. Once a term has been declared, suppliers will have to remove that term from all identical contracts, and refrain from including it in any future contracts identical to that subject to a declaration. So long as they comply with that post-declaration, they will be able to avoid prosecution.

A party to the contract with an unfair term declaration does have recourse to the Court by virtue of Part 5 of the FTA, which provides civil remedies as well as prescribing the criminal offences just described. In essence, a party may seek injunctive relief preventing a party from breaching Section 26A, ${ }^{44}$ and may seek an Order to recover loss suffered as a result of a breach of Section 26A, by forcing a refund, payment, or specific performance. $^{45}$

The idea of the usually robust civil and criminal provisions in Part 5 of the FTA on the face of it sounds appealing. However, there are a number of difficulties with the enforcement regime as enacted, when assessing the unfair terms provisions as a whole. The biggest of these arises by virtue of the mandatory requirement providing that the Court must consider the contract as a whole, and the transparency of the term in question, in declaring a term unfair. ${ }^{46}$ What this means, is that even if a supplier has had one term within their standard form contract declared unfair, they may be able to a) alter other terms of the contract to balance it out, b) make the term more transparent, or (c) combine both measures to ensure they have a complete defence against any civil proceedings, or prosecution that the Commerce Commission may wish to bring. The Commission would be left with no option but to return to Court seeking a fresh declaration on the term in light of its new context and transparency. Until such time as a declaration has been granted, the term may remain in force. Consumers may be left out of pocket, having

\footnotetext{
42 Section 40.

${ }^{43}$ Sound Plus Ltd v Commerce Commission [1991] 3 NZLR 329; Adair v Commerce Commission (1995) 5 NZBLC 103,615; Manufacturers Ltd v Commerce Commission [1991] 2 NZLR 502 and Fastlane Autos Ltd $v$ Commerce Commission [2004] 3 NZLR 513.

${ }^{44}$ Section 41.

${ }^{45}$ Section 43.

${ }^{46}$ Section $46 \mathrm{~L}(2)$.
} 
incurred losses before a term was declared unfair and thus before any breach of Section 26A occurred.

There appears to be no provision for parties that have previously been subject to enforcement of terms subsequently declared unfair. The family that have lost their interest in a house that they were occupying for ten years in a rent-to-own scheme have no recourse, if they have been ejected prior to an unfair term being declared as such. The Court's hands are tied, in that they are prevented from assessing the unfairness of a term for consumers who are subject to enforcement proceedings. Do we expect the Court to stay proceedings and ask the Commerce Commission to bring an application for a declaration? Even if the Court did take such an extraordinary step, the Commerce Commission would be under no legal obligation to do so, as their role as gate-keepers for this protection comes with no obligation to act. The Court can not declare a term unfair on its own motion. Even presuming the Commerce Commission has both the resources and the inclination to apply for a declaration every time it is warranted, the effect of such a declaration may only provide a temporary respite for those currently facing detriment from a particular term. Those that have already suffered will be out of luck.

\section{Conclusion}

The net effect of the monumental differences between the ACL and the new provisions to the FTA is yet to be seen. This paper concludes that the introduction of unfair terms provisions provides protection in form but not substance. The benefit of having the exclusive right to bring these cases rest in one public body is greatly outweighed by the problems it creates in enabling consumers to enforce their legal rights. A frank assessment of credible scenarios sees courts being forced to ignore the fact that a particular term relied upon by a supplier in enforcement proceedings taken against a consumer is objectively unfair.

Even when the Commerce Commission does act, and successfully obtains a declaration from the Court, not all consumers will automatically benefit from that declaration. Even a consumer under an almost identical contract with the same supplier may face the argument that because there is a difference in price, for example, the term in question is not unfair when read with the contract as a whole. 
Terms may be able to escape being declared unfair, despite an objective unfairness, by being exempt as forming part of the "upfront price" through the clever drafting of standard form contracts.

The emergence of consumer protection from unfair terms in standard form contracts in various jurisdictions reflects the fact that the behavioral science studies consistently show there is a need for legislative intervention. There are clear examples of situations where neither classical contract law nor other consumer protections provide assistance in cases that offend common sense and justice. The New Zealand legislature responded with what on its face appeared to be adopting provisions identical to the ACL, to bring our laws in line with those in Australia. What has been enacted, this paper concludes, due to the omission of private remedies and expansion of excluded terms, fails in its goal of providing consumers with substantive protection from unfair terms. We are left with protection in form but not substance. 


\section{BIBLIOGRAPHY}

\section{PRIMARY SOURCES}

1 Legislation

Fair Trading Amendment Act 2013 (NZ)

Fair Trading Act 1986 (NZ)

Consumer Guarantees Act 1986 (NZ)

Australian Consumer Law, Schedule 2, Competition and Consumer Act 2010 (Aus)

2 Cases

Sound Plus Ltd v Commerce Commission [1991] 3 NZLR 329

Adair v Commerce Commission (1995) 5 NZBLC 103,615

Manufacturers Ltd v Commerce Commission [1991] 2 NZLR 502

Fastlane Autos Ltd v Commerce Commission [2004] 3 NZLR 513

Jetstar Airways Pty Ltd v Free [2008] VSC 539 (Aus)

Director of Consumer Affairs Victoria v AAPT Limited [2006] VCAT 1493 (Aus)

SECONDARY SOURCES

1 Bills, Select Committee Reports \& Hansard Materials

Consumer Law Reform Bill 2012 (287-2), as reported from the Commerce Committee on 2 October 2012. 
Fair Trading Amendment Bill 2013 (287-3A), as reported from the committee of the whole House on 3 December 2013.

New Zealand Parliamentary Debates, 9 February 2012, Volume 677, Page 283. Minister of Consumer Affairs moves for first reading of the bill.

New Zealand Parliamentary Debates, 11 December 2012. Volume 686; Page 7410. Minister of Consumer Affairs moves for second reading of the bill.

New Zealand Parliamentary Debates, 10 December 2013, Volume 695, Page 15389. Minister of Immigration, on behalf of minister of Consumer Affairs, moves for the third reading of the bill (omnibus bill split at this point).

\section{Submissions made to Select Committee}

Submission by Business New Zealand to the Commerce Committee on the Consumer Law Reform Bill, dated 29 March 2012.

Submission by Auckland District Law Society Incorporated to the Commerce Committee on the Consumer Law Reform Bill, undated, sent 5 April 2012.

Submission by the Commerce Commission to the Commerce Committee on the Consumer Law Reform Bill, dated March 2012.

Submission by the New Zealand Law Society to the Commerce Committee on the Consumer Law Reform Bill, dated 2 April 2012.

Submission by the New Zealand Bankers Association to the Commerce Committee on the Consumer Law Reform Bill, dated 29 March 2012.

\section{Official Material}

New Zealand Commerce Commission Draft Unfair Contract Terms Guidelines (July 2014)

Ministry of Consumer Affairs, Consumer Law Reform: A Discussion Paper, 2010. 
Ministry of Consumer Affairs, Consumer Law Reform Additional Paper, September 2010.

Submissions on additional paper:

New Zealand Retailers Association, Consolidated Response to the Ministry of Consumer Affairs Consumer Law Reform Additional Discussion Papers, November 2010

Auckland District Law Society Inc, Commercial Law Committee Submissions to the Ministry of Consumer Affairs In Response to Consumer Law Reform Additonal Paper September 2010 Unfair Contract Terms

AMI Insurance Limited Submission on the Consumer Law Reform Additional Paper September 2010 Unfair Contract Terms.

Consumer NZ Submission on Consumer Law Reform Additional Paper: Unfair Contract Terms

Dunedin Community Law Centre, Submission on Consumer Law Reform Additional Paper - September 2010, Unfair Contract Terms

\section{Journals and Articles}

Reforming Consumer Law [2014] CSLB No 1

Alexandra Sims, Unfair Contract Terms: a New Dawn in Australia and New Zealand? Monash University Law Revue, 39.3 (Dec 2013) p739.

Ben-Shahar, Omri, The Myth of the 'Opportunity to Read' in Contract [2009] 1 ERCL 1. U of Chicago Law \& Economics, Olin Working Paper No. 415. Available at SSRN: http://ssrn.com/abstract=1162922 or http://dx.doi.org/10.2139/ssrn.1162922

Law, Stephanie and Cafaggi, Fabrizio, Unfair Contract Terms - Effect of Collective Proceedings - C-472-10, Invitel (August 5, 2013). Forthcoming in Evelyne Terryn, Gert Straetmans and Veerle Colaert (eds.) Landmark Cases of EU Consumer Law - In Honour 
of Jules Stuyck (Intersentia, 2013). Available at SSRN: http://ssrn.com/abstract=2306024 or http://dx.doi.org/10.2139/ssrn.2306024

Martin, Jennifer S., An Emerging Worldwide Standard for Protections of Consumers in the Sale of Goods: Did We Miss an Opportunity with Revised UCC Article 2?. Texas International Law Journal, Vol. 41, No. 223, 2006. Available at SSRN: http://ssrn.com/abstract $=1019557$

Becher, Shmuel I., Behavioral Science and Consumer Standard Form Contracts. Louisiana Law Review, Vol. 68, 2007. Available at SSRN: http://ssrn.com/abstract=1016002

Paterson, Jeannie Marie, The Australian Unfair Contract Terms Law: The Rise of Substantive Unfairness as a Ground for Review of Standard Form Consumer Contracts (August, 30 2010). Melbourne University Law Review, Vol. 33, No. 3, 2009; U of Melbourne Legal Studies Research Paper No. 494. Available at SSRN: http://ssrn.com/abstract $=1669008$

Twigg-Flesner, Christian, The Implementation of the Unfair Contract Terms Directive in the United Kingdom (November 30, 2007). Contemporary Issues in Law, 2006/2007. Available at SSRN: http://ssrn.com/abstract=1399631

\section{Books \& Chapters}

S G Corones (ed) The Australian Consumer Law ( $2^{\text {nd }}$ Ed, Thompson Routers, Sydney, 2012)

J Malbon \& L Nottage (eds) Consumer Law \& Policy in Australia and New Zealand (The Federation Press, Sydney, 2013)

\section{Online Material}

Press Release by Minister of Consumer Affairs, 10 December 2013. $<$ http://www.beehive.govt.nz/release/consumer-law-reform-bill-passes-third-reading $>$ 
Dr P Bender Australian Consumer Law: Unfair Contracts and Other Litigation, July 2013

$<$ http://barristers.com.au/wp-content/uploads/2012/07/Australian-Consumer-Law-UnfairContracts-by-Dr-Philip-Bender.pdf $>$ 